\title{
Antiviral effect of phytochemicals from medicinal plants: Applications and drug delivery strategies
}

\author{
Shimon Ben-Shabat ${ }^{1} \cdot$ Ludmila Yarmolinsky $^{2} \cdot$ Daniel Porat $^{1} \cdot$ Arik Dahan $^{1}$ (I) \\ Published online: 1 December 2019 \\ (C) Controlled Release Society 2019
}

\begin{abstract}
Viral infections affect three to five million patients annually. While commonly used antivirals often show limited efficacy and serious adverse effects, herbal extracts have been in use for medicinal purposes since ancient times and are known for their antiviral properties and more tolerable side effects. Thus, naturally based pharmacotherapy may be a proper alternative for treating viral diseases. With that in mind, various pharmaceutical formulations and delivery systems including micelles, nanoparticles, nanosuspensions, solid dispersions, microspheres and crystals, self-nanoemulsifying and self-microemulsifying drug delivery systems (SNEDDS and SMEDDS) have been developed and used for antiviral delivery of natural products. These diverse technologies offer effective and reliable delivery of medicinal phytochemicals. Given the challenges and possibilities of antiviral treatment, this review provides the verified data on the medicinal plants and related herbal substances with antiviral activity, as well as applied strategies for the delivery of these plant extracts and biologically active phytochemicals.
\end{abstract}

Keywords Antiviral $\cdot$ Phytomedicine $\cdot$ Herbal extracts $\cdot$ Flavonoid $\cdot$ Solubility $\cdot$ Oral drug delivery

\section{Introduction}

Viral infections remain a major worldwide cause of morbidity and mortality. Among the most aggressive viral infections are Ebola, AIDS (acquired immunodeficiency syndrome), influenza, and SARS (severe acute respiratory syndrome). For instance, influenza is responsible for over 3 million new cases of severe disease, and between 300,000-500,000 deaths yearly $[1,2]$. Alarmingly, the number of patients diagnosed with viral infections is increasing every year with more blood transfusions, organ transplantations, and the use of hypodermic syringes.

Shimon Ben-Shabat

sbs@bgu.ac.il

Arik Dahan

arikd@bgu.ac.il

1 Department of Clinical Biochemistry and Pharmacology, Faculty of Health Sciences, Ben-Gurion University of the Negev, 8410501 Beer-Sheva, Israel

2 Eastern R\&D Center, Kiryat Arba, Israel
Classic antiviral drugs such as interferon and ribavirin are effective in vitro against most viruses, but often are ineffective in patients. Ninety different antiviral agents available today [3, 4] only treat a selection of viruses; these viruses include HIV (human immunodeficiency virus), herpes viruses, including HSV (herpes simplex virus), hCMV (human cytomegalovirus), VZV (varicella zoster virus), influenza viruses, and the hepatitis viruses (Fig. 1). Currently, there is no approved remedy for many types or viruses, and vaccination is limited to hepatitis A virus, mumps, and varicella [2]. In addition, these agents are often costly and ineffective due to viral resistance and cause side effects. With that in mind, naturally based pharmacotherapy may be a proper alternative for treating viral diseases. Thus, it is necessary to further examine the topic of antiviral phytochemicals, highlighting drug delivery applications in overcoming the multiple biological barriers existing for antiviral agents to successfully reach their intended site(s) of action. The present review focuses on the antiviral properties of herb extracts and bioactive constituent isolates from medicinal plants, and the efforts to obtain their efficient delivery. 


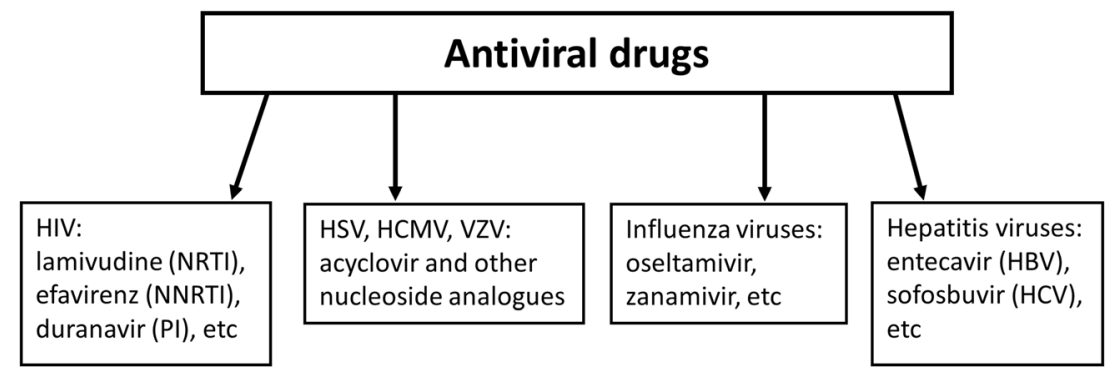

Fig. 1 Antiviral drugs. The antiviral drugs are used for HIV (human immunodeficiency virus), herpes viruses, influenza A and B viruses, and the HBV (hepatitis B) and HCV (hepatitis C) viruses. Some of the

\section{Antiviral medicinal plants and phytochemicals}

Various plants have been used in medicine since ancient times and are known for their strong therapeutic effect. In traditional medicine, diseases of possible viral origin have been treated by many of these plants. The main findings related to antiviral plant extracts are collected in Table 1. Included extracts were tested in cell culture, and some extracts were also studied in vivo $[11,23,31,39]$.

Various phytochemicals were isolated, purified, and identified from the crude extracts of alkaloids, terpenes, flavonoids, various glycosides, and proteins (Table 1). Compounds with antiviral activity are present in many plants, e.g., rutin, a flavonoid glycoside common in different plants, is effective against avian influenza virus [48], HSV-1, HSV-2 [18], and parainfluenza-3 virus [49].

Quercetin, an aglycone of rutin, is a phytochemical abundant in plants and may diminish the replication of many viruses: highly pathogenic influenza virus [50], rhinovirus [51], dengue virus type-2 [52], HSV-1 [53], poliovirus [54], adenovirus [53], Epstein-Barr virus [55], Mayaro virus [56], Japanese encephalitis virus [57], respiratory syncytial virus [58], and $\mathrm{HCV}[59,60]$. Its antiviral activity mode was studies in a few cases. Its ability to inhibit HCV by limiting the activity of some heat shock proteins (HSPs) produced by cells in response to exposure to stress which were involved in NS5A (nonstructural protein 5A)-mediated viral IRES (internal ribosome entry site) translation [60] is one well-known mechanism. Another mechanism involved the inhibition of HCV NS3 protease and HCV replication in a subgenomic HCV RNA replicon cell system [59]. Quercetin also inhibits various steps of the rhinoviruses pathogenesis, i.e., endocytosis, viral genome transcription, and protein synthesis [51]. In another case, quercetin was shown to have a more specific mode of action, reducing the replication of dengue virus type-2, but not the processes of viral attachment and entry [52].

In addition, quercetin and three other flavonoids: $3,3^{\prime}, 4^{\prime}, 5,5^{\prime}, 7$-hexahydroxyflavone (myricetin), 3,3', $4^{\prime}, 5,6,7$ hexahydroxyflavone (quercetagetin), and 5,6,7trihydroxyflavone (baicalein), all effectively inhibited reverse transcriptases from Rauscher murine leukemia virus (RLV) commonly prescribed antiviral drugs are given. NRTI, nucleoside reverse transcriptase inhibitor; NNRTI, non-nucleoside reverse transcriptase inhibitor; PI, protease inhibitor

and HIV; quercetin, myricetin, and quercetagetin were also shown to inhibit different DNA polymerase enzymes [61]. The abovementioned flavonoid, myricetin, is abundant in wild plants, nuts, fruits, berries, and vegetables. Ellagic acid and myricetin (from the aronia fruit) were active in cell cultures against different subtypes of influenza viruses including an oseltamivir-resistant strain, and also effective in vivo [62].

Apigenin (4',5,7-trihydroxyflavone), an aglycone of the flavone class, is found in many plants and has broad antiviral activities against enterovirus-71 [63], foot and mouth disease virus [64], HCV [65], African swine fever virus (ASFV) [66], and influenza A virus [67]. Of note, many flavonoids of plant origin have known antiviral properties. For example, out of 22 different flavonoids, six phytochemicals (apigenin, baicalein, biochanin A, kaempferol, luteolin, naringenin) were active against the avian influenza $\mathrm{H} 5 \mathrm{~N} 1$ virus in human lung epithelial (A549) cells through inhibiting nucleoprotein production [67]. Baicalin (the glucuronide of baicalein) was also active against a wide range of viruses, including enterovirus [68], dengue virus [69], respiratory syncytial virus [70], Newcastle disease virus [71], human immunodeficiency virus [72], and hepatitis B virus [73], and different mechanisms were suggested for its antiviral actions. For example, baicalin inhibits the production of HBV, the templates for viral proteins and HBV-DNA synthesis [73], and decreases IL- 6 and IL- 8 production without affecting IP-10 levels, as shown in a study on avian influenza H5N1 virus [67].

The triterpenoids oleanolic acid and ursolic acid are abundant in the plant kingdom, may be effective against $\mathrm{HCV}$ by reducing HCV NS5B RdRp virulence [74], and can also inhibit enterovirus 71 replication [75]. Lastly, Sambucus nigra L. is an active ingredient in a standardized elderberry extract, effectively used in the treatment of fever, colds, and influenza A and B [76-78].

\section{Delivery of herbal extracts and phytochemicals}

Introducing pharmaceutical nanotechnology into the field of natural medicine is useful and promising. New strategies for the delivery of poorly soluble phytochemicals and plant extracts allow improved pharmacokinetic and clinical outcomes. 
Table 1 Antiviral properties of plant extracts

\begin{tabular}{|c|c|c|c|c|}
\hline Plant & Kind of extract & Virus & Phytochemicals & References \\
\hline $\begin{array}{l}\text { Achillea } \\
\quad \text { fragrantissima }\end{array}$ & Hydro-alcoholic extract & Poliomyelitis-1 virus (POLIO) & Unknown & {$[3]$} \\
\hline Aegle marmelos & Aqueous extract & Human coxsackieviruses B1-B6 & Unknown & {$[4]$} \\
\hline Aloe vera & Glycerine extract & HSV-2 & Unknown & [5] \\
\hline Artocarpus integrifolia & Aqueous extract & $\begin{array}{l}\text { (SA-11) and human (HCR3) } \\
\text { rotaviruses }\end{array}$ & Unknown & [6] \\
\hline Balanites aegyptiaca & n-Hexane extract & VSV T2 & Unknown & [7] \\
\hline Camellia sinensis & Aqueous extracts & HBV & Epigallocathechin-3-gallate & [8] \\
\hline Capparis spinosa & Methanolic extract & $\begin{array}{l}\text { HSV-2 } \\
\text { HIV-1 }\end{array}$ & $\begin{array}{l}\text { Unknown } \\
\text { Protein }\end{array}$ & [9] \\
\hline Cassine xylocarpa & Aqueous extract & HIV & Pentacyclic lupane-type triterpenoids & {$[10]$} \\
\hline Cistus incanus & $\begin{array}{l}\text { Polyphenol-rich extract } \\
\text { (CYSTUS052) }\end{array}$ & $\begin{array}{l}\text { Avian and human influenza } \\
\text { strains } \\
\text { of different subtypes } \\
\text { HIV-1 and HIV-2 }\end{array}$ & $\begin{array}{l}\text { Unknown } \\
\text { Unknown }\end{array}$ & $\begin{array}{l}{[11,12]} \\
{[13]}\end{array}$ \\
\hline Curcuma longa & Aqueous extract & HSV-1 & Curcumin & {$[5]$} \\
\hline Cyperus rotundus & Hydro-alcoholic extract & $\begin{array}{l}\text { HSV-1 } \\
\text { HBV }\end{array}$ & $\begin{array}{l}\text { Unknown } \\
\text { cyperene-3, 8-dione, 14-hydroxy } \\
\text { cyperotundone, 14-acetoxy } \\
\text { cyperotundone, 3 } \beta \text {-hydroxycyperenoic } \\
\text { acid and sugetriol-3, 9-diacetate }\end{array}$ & {$[3,14]$} \\
\hline Daphne gnidium & Hydro-alcoholic extract & HIV & $\begin{array}{l}\text { Daphnetoxin, gnidicin, gniditrin and } \\
\text { excoecariatoxin }\end{array}$ & {$[15]$} \\
\hline Diospyros kaki & Aqueous extract & Human rotavirus & $\begin{array}{l}\text { Licocoumarone, licoflavonol, } \\
\text { glyasperin D, } 18 \beta \text {-glycyrrhetinic } \\
\text { acid, luteolin, vitexin, } \\
\text { apigenin-7-O-glucoside }\end{array}$ & {$[6]$} \\
\hline Dittrichia viscosa & Aqueous extract & VSV, HSV-1, poliovirus type 1 & Unknown & {$[16]$} \\
\hline Euphorbia hirta & $\begin{array}{l}\text { Aqueous extracts, methanol } \\
\text { extracts }\end{array}$ & HIV-1, HIV-2, SIV mac 251 & Unknown & {$[17]$} \\
\hline Euphorbia spinidens & Methanol extract & HSV-1 & Unknown & {$[5]$} \\
\hline Ficus benjamina & Ethanol extract & HSV-1, HSV-2 & $\begin{array}{l}\text { Rutin, kaempferol 3-O-rutinoside and } \\
\text { kaempferol 3-O-robinobioside }\end{array}$ & {$[18]$} \\
\hline Ficus carica & $\begin{array}{l}\text { Aqueous extract } \\
\text { The hexanic and hexane-ethyl } \\
\text { acetate from latex of fig fruit } \\
\text { Hexanic extract }\end{array}$ & $\begin{array}{l}\text { HSV-1 } \\
\text { HSV-1, ECV-11 and ADV } \\
\text { influenza virus }\end{array}$ & Unknown & $\begin{array}{l}{[19]} \\
{[20]} \\
{[21]}\end{array}$ \\
\hline Globularia arabica & Hydro-alcoholic extract & Poliomyelitis-1 virus (POLIO) & Unknown & {$[3]$} \\
\hline Glycyrrhiza glabra & Methanolic extract & NDV & Unknown & {$[22]$} \\
\hline Glycyrrhiza uralensis & Metabolic extract & Rotavirus diarrhea & Unknown & {$[23]$} \\
\hline Hyssopus officinalis & Methanolic extract & HSV-1 & Unknown & [5] \\
\hline Leucojum vernum & Methanolic extract & HIV-1 & Homolycorine and 2-O-acetyllycorine & {$[24]$} \\
\hline Lilium candidum & Ethanol extract & HSV-1, HSV-2 & Kaempferol & {$[25]$} \\
\hline Magnolia officinalis & Methanol extract & Dengue virus Type 2 & Honokiol & {$[26]$} \\
\hline Maytenus cuzcoina & Aqueous extract & HIV & Pentacyclic lupane-type triterpenoids & {$[10]$} \\
\hline Melissa officinalis & Aqueous extract & $\begin{array}{l}\text { HSV-1 } \\
\text { HSV-1, HSV-2 } \\
\text { HIV }\end{array}$ & Unknown & $\begin{array}{l}{[27]} \\
{[28]} \\
{[29]}\end{array}$ \\
\hline Mentha pulegium & Methanolic extract & HSV-1 & Unknown & {$[30]$} \\
\hline Moringa peregrina & Hydro-alcoholic extract & HSV-1 & Unknown & {$[3]$} \\
\hline Myristica fragrans & Aqueous extract & Human rotavirus & Unknown & {$[6]$} \\
\hline Olea europaea & Hexanic extract & Influenza virus subtype H9N2 & Unknown & {$[21]$} \\
\hline Panax ginseng & Methanolic extract & Human rotavirus & $\begin{array}{l}\text { Epigallocatechin gallate, theaflavin } \\
\text { digallate, genistein, hesperidin, } \\
\text { neohesperidin, diosmin, pectic } \\
\text { polysaccharides }\end{array}$ & {$[6]$} \\
\hline
\end{tabular}


Table 1 (continued)

\begin{tabular}{|c|c|c|c|c|}
\hline Plant & Kind of extract & Virus & Phytochemicals & References \\
\hline Panax notoginseng & Aqueous extract & Influenza A virus & Unknown & {$[31]$} \\
\hline Phyllanthus acidus & Aqueous extract & $\mathrm{HBV}$ & $\begin{array}{l}\text { Highly oxygenated norbisabolane } \\
\text { sesquiterpenoids, phyllanthacidoid } \\
\text { acid methyl ester }\end{array}$ & {$[32]$} \\
\hline \multirow[t]{2}{*}{ Phyllanthus emblica } & Aqueous extract & Influenza A virus strain $\mathrm{H} 3 \mathrm{~N} 2$ & \multirow{2}{*}{$\begin{array}{l}\text { Highly oxygenated norbisabolane } \\
\text { sesquiterpenoids } \\
\text { Sesquiterpenoid glycoside dimers }\end{array}$} & {$[33]$} \\
\hline & Aqueous extract & $\mathrm{HBV}$ & & {$[34]$} \\
\hline \multirow[t]{2}{*}{ Prunella vulgaris } & \multirow[t]{2}{*}{ Aqueous extract } & HIV-1 & \multirow[t]{2}{*}{ Unknown } & {$[35]$} \\
\hline & & Ebola virus & & {$[36]$} \\
\hline $\begin{array}{l}\text { Quercus brantii } L \\
\text { Acorn. }\end{array}$ & Ethanol extract & HSV-1 & Unknown & {$[37]$} \\
\hline Quercus persica & Hydroalchoholic extract & HSV-1 & Unknown & {$[38]$} \\
\hline Salacia reticulata & Aqueous extract & H1N1 influenza & \multirow[t]{3}{*}{ Unknown } & [39] \\
\hline \multirow[t]{2}{*}{ Sanguisorba minor } & \multirow[t]{2}{*}{ Aqueous extract } & VSV, HSV-1 & & {$[16]$} \\
\hline & & HIV & & {$[40]$} \\
\hline Securigera securidaca & Methanol extract & HSV-1, HSV-2 & Unknown & [5] \\
\hline Solanum nigrum & $\begin{array}{l}\text { Methanol and chloroform } \\
\text { extracts of seeds }\end{array}$ & $\mathrm{HCV}$ & Unknown & {$[41]$} \\
\hline Spondias lutea & Aqueous extract & Human rotavirus & Unknown & {$[6]$} \\
\hline Tamarix nilotica & Hydro-alcoholic extract & HSV-1 & Unknown & {$[3]$} \\
\hline \multirow[t]{2}{*}{ Taraxacum officinale } & Methanol extract & $\mathrm{HCV}$ & \multirow[t]{2}{*}{ Unknown } & [42] \\
\hline & Aqueous extract & Influenza virus type A, H1N1. & & [43] \\
\hline Thymus carmanicus & Methanol extract & HIV-1 & Unknown & {$[44]$} \\
\hline Thymus daenensis & Methanol extract & HIV-1 & Unknown & [44] \\
\hline Thymus kotschyanus & Methanol extract & HIV-1 & Unknown & {$[44]$} \\
\hline Thymus vulgaris & Methanol extract & HIV-1 & Unknown & [44] \\
\hline Tuberaria lignosa & An aqueous extract & HIV & Ellagic acid derivative & {$[45]$} \\
\hline Viola diffusa & Ethanol extract & HBV & 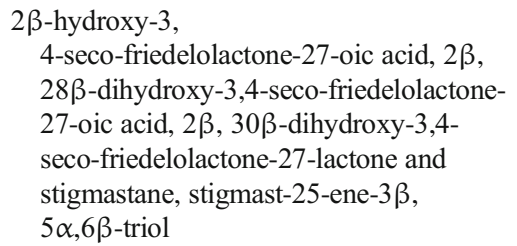 & [46] \\
\hline Vitis labrusca & Methanol extract & $\begin{array}{l}\text { (SA-11) and human (HCR3) } \\
\text { rotaviruses }\end{array}$ & $\begin{array}{l}\text { Resveratrol, piceatannol, } \\
\text { trans-arachidin-1 and trans-arachidin-3 }\end{array}$ & [6] \\
\hline Vitis macrocarpon & Methanol extract & $\begin{array}{l}\text { (SA-11) and human (HCR3) } \\
\text { rotaviruses }\end{array}$ & $\begin{array}{l}\text { Abietic acid, all-trans-retinoic acid, } \\
\text { mangostin, } \alpha \text {-glucosyl hesperidin, } \\
\text { proanthocyanidins }\end{array}$ & {$[6]$} \\
\hline Zataria multiflora & Methanolic extract & HSV-1 & Rosmarinic acid & {$[47]$} \\
\hline
\end{tabular}

$H S V$ herpes simplex virus, $V S V$ vesicular stomatitis virus, $H B V$ hepatitis B virus, $H I V$ human immunodeficiency virus, $S I V$ simian immunodeficiency virus, $E C V$ echovirus, $A D V$ adenovirus, $N D V$ Newcastle disease virus, $H C V$ hepatitis $\mathrm{C}$ virus

Commonly used approached such as phytosomes, nanoparticles, hydrogels, microspheres, transferosomes and ethosomes, self-microemulsifying drug delivery systems (SMEDDS), and self-nanoemulsifying drug delivery systems (SNEDDS) have been applied for the delivery of antiviral plant agents (Table 2). These antiviral technologies may be preferred over older phytochemical drug formulations due to enhanced solubility and oral absorption, systemic bioavailability, safety, delayed metabolism, and better overall antiviral activity. Yet, very few papers have been published on the topic of antiviral herbal drug delivery, so we wish to display several successful attempts of improving the delivery of phytodrugs with known antiviral activity. Qian et al. [79] attempted to design a selfnanoemulsifying drug delivery system (SNEDDS) to allow greater apparent solubility and oral bioavailability $(<10 \%)$ of myricetin. Overall, four formulations were prepared, F04 (Capryol 90/Cremophor RH 40/PEG 400 in a 4:3:3 ratio), F08 (Capryol 90/Cremophor RH 40/1,2-propanediol 4:3:3), F13 (Capryol 90/Cremophor EL/Transcutol HP 4:3:3), and F15 (Capryol 90/Cremophor RH 40/Transcutol HP 2:7:1), and the solubility of myricetin in different excipients was 
Table 2 Summary of the different applied delivery systems for antiviral phytochemicals

\begin{tabular}{|c|c|c|}
\hline Phytochemical & Viruses & Delivery system/method \\
\hline Myricetin & HIV, RLV, influenza & $\begin{array}{l}\text { SNEDDS [79], nanogel [80], mixed micelles [81], nanosuspension [82], } \\
\text { cocrystal [83], nanoencapsulation [84] }\end{array}$ \\
\hline Apigenin & $\begin{array}{l}\text { Enterovirus 71, FMDV, HCV, } \\
\text { ASFV, influenza A }\end{array}$ & $\begin{array}{l}\text { W/O/W emulsion [85], O/W microemulsion [86], solid dispersion [87, } \\
\text { 88], mixed micelles [89], phospholipid phytosome [90], pellets [91], } \\
\text { SMEDDS [92] }\end{array}$ \\
\hline Baicalin & $\begin{array}{l}\text { Influenza, NDV, enterovirus } 71 \text {, } \\
\text { DENV, RSV, HIV, HBV }\end{array}$ & $\begin{array}{l}\text { Liposome [93], mixed micelles [94, 95], polymeric micelles [96], } \\
\text { SNEDDS [97], nanoemulsion [98], inclusion complex [99], solid } \\
\text { dispersion [100], nanoparticles [101], nanocrystals [102, 103], } \\
\text { SMEDDS [104] }\end{array}$ \\
\hline Quercetin & $\begin{array}{l}\text { JEV, influenza A, EBV, } \\
\text { MAYV, RV, HCV }\end{array}$ & $\begin{array}{l}\text { Nanocrystal [105], nanoparticles [106-110], phytosome [111], } \\
\text { nanoliposome [112], mixed micelles [113, 114], SNEDDS }[115,116] \\
\text { nanocarrier }[117,118], \text { nanoemulsion }[119], \text { nanosuspension }[120]\end{array}$ \\
\hline Fructus Forsythiae extracts & Influenza, RSV & chito-oligosaccharide $[121,122]$ \\
\hline Flos Lonicerae extracts & Influenza, RSV, HIV, NDV & chito-oligosaccharide [122] \\
\hline Andrographolide & $\begin{array}{l}\text { DENV, CHIKV, HPV16 } \\
\text { pseudovirus, influenza, } \\
\text { HBV, HCV, HSV1, EBV, HIV }\end{array}$ & $\begin{array}{l}\text { SMEDDS [123], microspheres [124], nanosuspension [125], } \\
\text { self-nanodispersion [126], nanoparticles [127], inclusion complex } \\
\text { [128] }\end{array}$ \\
\hline Curcumin & $\begin{array}{l}\text { Influenza, RSV, HBV, HCV, } \\
\text { ZIKV, CHIKV, norovirus, } \\
\text { HIV, HPV, CMV, EV71, } \\
\text { DENV type-2 }\end{array}$ & $\begin{array}{l}\text { Mixed micelles [129, 130], nanoparticles [131, 132], solid dispersion } \\
{[133,134], \text { SNEDDS [135], SMEDDS [136], lipid carrier [137], }} \\
\text { copolymeric micelles [138], exosomes [139] }\end{array}$ \\
\hline Naringenin & DENV, HCV & $\begin{array}{l}\text { SNEDDS [140], solid dispersion [141], nanoparticles [142, 143], } \\
\text { liposome [144], nanosuspension [145, 146], cyclodextrin complex [147] }\end{array}$ \\
\hline Honokiol & DENV, HCV & Inclusion complex [148], conjugate micelles [149], nanoparticles [150] \\
\hline Oleanolic acid & Acute and chronic hepatitis & $\begin{array}{l}\text { SMEDDS [151], nanoparticles [152], nanosuspensions } \\
{[153,154], \text { SNEDDS [155] }}\end{array}$ \\
\hline
\end{tabular}

$H I V$ human immunodeficiency virus, $R L V$ rhesus lymphocryptovirus, $F M D V$ foot and mouth disease virus, $H C V$ hepatitis $\mathrm{C}$ virus, $A S F V$ African swine fever virus, $N D V$ Newcastle disease virus, $D E N V$ dengue virus, $R S V$ respiratory syncytial virus, $H B V$ hepatitis B virus, $J E V$ Japanese encephalitis virus, $E B V$ Epstein-Barr virus, $M A Y V$ Mayaro virus, $R V$ rhinovirus, $C H I K V$ Chikungunya virus, $H P V$ human papilloma virus, $H S V$ herpes simplex virus, $Z I K V$ Zika virus, $C M V$ cytomegalovirus, $E V$ enterovirus, $S N E D D S$ self-nanoemulsifying drug delivery system, $W / O / W$ water-in-oil-in-water, $O / W$ oil-in-water, SMEDDS self-microemulsifying drug delivery system

studied. The optimized formulations underwent evaluation of release (dissolution), Caco-2 cell cytotoxicity and intestinal permeability studies in vitro, following by in vivo pharmacokinetics of myricetin-SNEDDS. Three of the four chosen formulations exhibited acceptable cell viability ( $>90 \%$ ), while the fourth formulation was slightly cell-toxic, probably because of high nonionic surfactant content (70\%). In vitro drug release testing demonstrated that myricetin alone had limited dissolution of $51 \%$ after an hour, whereas drug release for all SNEDDS formulations was over $90 \%$ after $1 \mathrm{~min}$. Single-pass intestinal perfusion (SPIP) method in rats showed that in the duodenum, the primary absorption site of myricetin, the effective permeability coefficient was significantly higher (1.2-2.2-fold, $p<$ 0.05 ) in all SNEDDS formulations relative to free myricetin, via inhibition of myricetin efflux by nonionic surfactants in SNEDDS (Fig. 2). In animal models, the myricetin-loaded SNEDDS formulations exhibited higher plasma myricetin concentrations in all time points compared to the free myricetin. Formulation No. 13 in Fig. 2 had higher intestinal permeability, but showed lower bioavailability attributed to poor lymphatic transport-a main absorption mechanism of myricetin.
Formulation No. 4 and 8 , on the other hand, achieved small particle size, required for lymphatic transport (Fig. 2).

Kim et al. [85] tried to increase the oral bioavailability of the low solubility flavonoid apigenin. Different water-in-oilin-water emulsions of apigenin were studied for their physical characteristics, as well as digestibility using in vitro digestion model and in vivo pharmacokinetics in rats. An emulsion of soybean oil-Tween 80 was chosen for pharmacokinetic tests in animal model after proving better stability in terms of particle size and zeta potential. Plasma concentrations of apigenin in the water-in-oil emulsion were markedly higher at different time points and maximal concentration was 9-fold higher compared to apigenin suspension [85].

Zhang et al. [94] aimed to improve the oral absorption of baicalin, which has low solubility and poor permeability, by using a micellar formulation comprised of the carriers Pluronic P123 copolymer and sodium taurocholate. Sustained release profile of baicalin-loaded mixed micelles, in in vitro drug release experiment, held in several $\mathrm{pH}$ conditions, showed $14 \%$ drug released after $2 \mathrm{~h}$ in gastric conditions and 54\% release within $48 \mathrm{~h}$ in intestinal conditions, compared to $34 \%$ and $79 \%$ release 
Fig. 2 Myricetin blood levels in rats after oral administration of 20 $\mathrm{mg} / \mathrm{kg}$ free myricetin or any of four different SNEDDS

formulations $(n=6)$; upper right: permeability coefficient $\left(P_{\text {eff }}\right)$ of myricetin in single-pass intestinal perfusion model $(n=3)$; F04, Capryol 90/Cremophor RH 40/ PEG 400 4:3:3; F08, Capryol 90/ Cremophor RH 40/1,2propanediol 4:3:3; F13, Capryol 90/Cremophor EL/Transcutol HP 4:3:3 and F15, Capryol 90/ Cremophor RH 40/Transcutol HP 2:7:1. Reproduced from [79] with permission

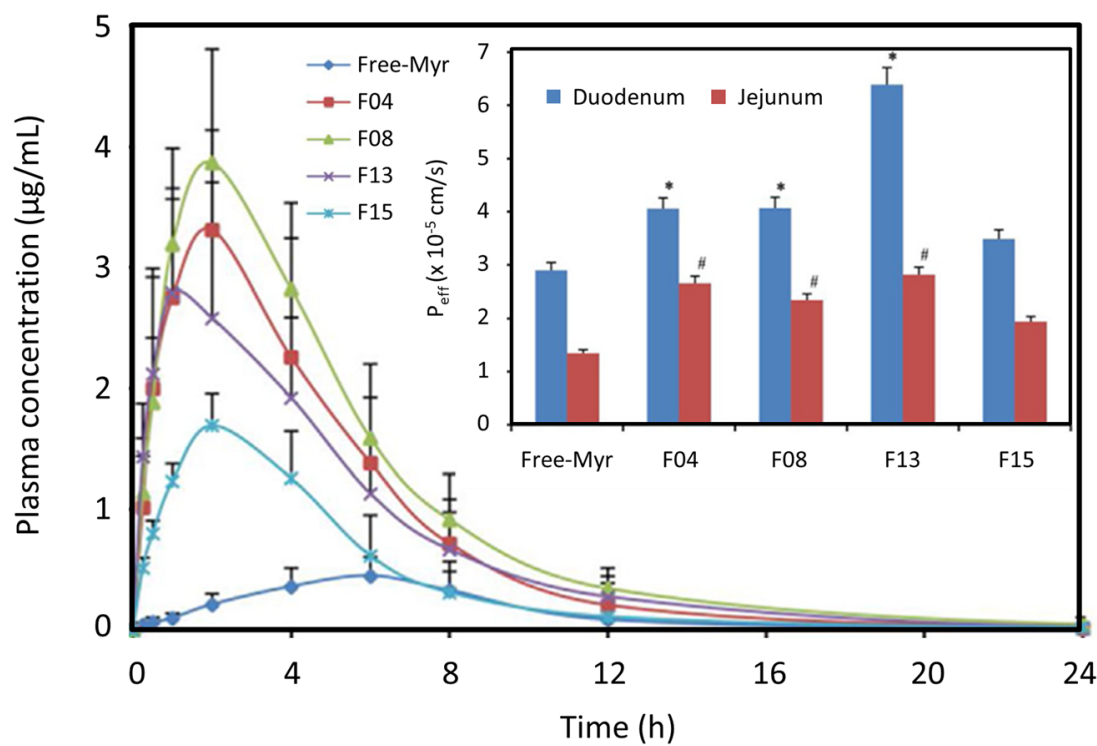

from a baicalin suspension, respectively. This observation suggests improved stability afforded by the designed formulation. In vitro uptake studies, carried out with a caco- 2 cell line, determined the absorption of baicalin within the mixed micelles and verified their internalization ability. Baicalin-loaded ST-P123MMs formulation achieved high oral bioavailability (Fig. 3). These results are believed to derive from the micellar small size and to Pluronic component, which is a P-glycoprotein inhibitor. In addition, the mixed micelle formulation showed a bimodal presentation, presumably attributed to enterohepatic recirculation, further enhancing the drug's oral bioavailability [94].

Oleanolic acid has low aqueous solubility and systemic bioavailability $(0.7 \%$ in rats). SMEDDS was developed in an attempt to overcome these limitations. This delivery system consisted of $50 \%$ ethyl oleate (oil), 35\% Cremophor EL (surfactant), and $15 \%$ alcohol (co-surfactant), allowing a great increase in oleanolic acid solubility [151]. In vitro studies showed a sustained release behavior from SMEDDS. Systemic rat bioavailability was significantly higher in SMEDDS than in the marketed tablets of oleanolic acid (Fig. 4). The improved drug's oral bioavailability was explained by enhanced solubility and permeability through emulsification and small particle sizes, respectively.

Flos Lonicerae Japonicae and Fructus forsythia are used together in Chinese herbal remedies, and both have antiviral, antibacterial, and antiinflammatory properties. An attempt was made to enhance the bioavailability and antiinfluenza properties of the herb combination by chito-oligosaccharide, a chitosan derivative [122]. In a cell culture antiinfluenza assay, chito-oligosaccharide improved the activity of extracts containing Flos Lonicerae Japonicae and Fructus forsythia, compared to extracts that do not contain the chito-oligosaccharide. The absorption was studied in vitro using Caco-2 model, and higher experimentally derived apparent permeability values were obtained with increasing concentrations
Fig. 3 Baicalin blood levels after oral administration of baicalin (BC) and BC-loaded ST-P123MMs (P123, an amphipathic polymer and sodium taurocholate as a carrier); upper right: drug release of baicalin. Reproduced from [94] with permission

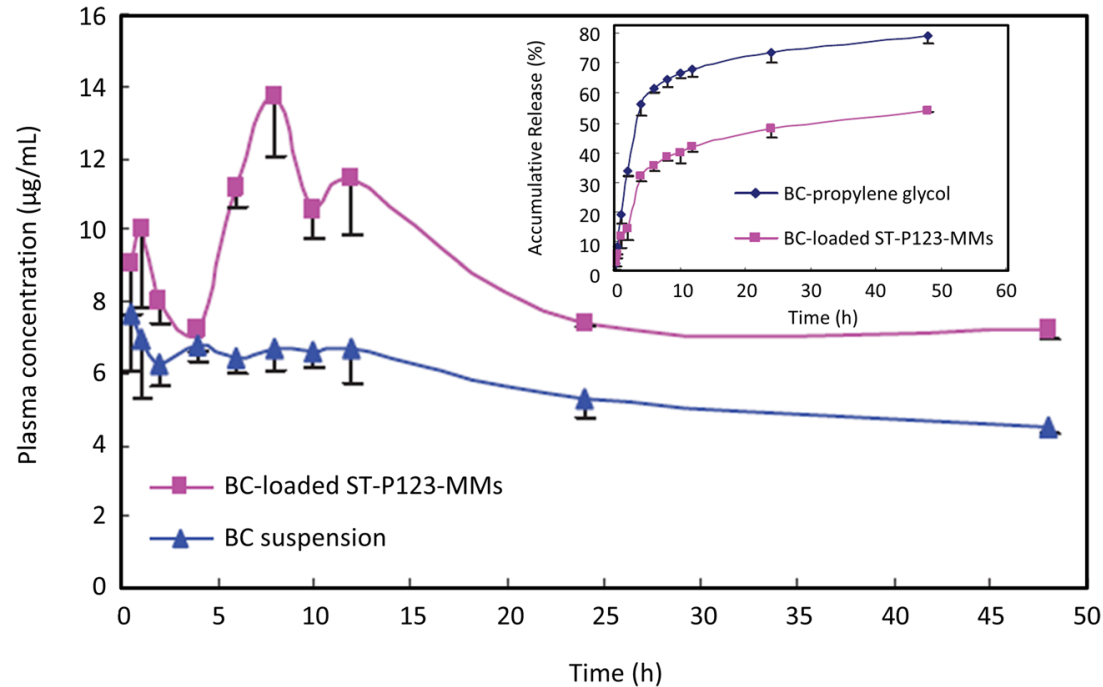


Fig. 4 Oleanolic acid rat blood levels after oral administration of oleanolic acid-loaded SMEDDS (filled diamonds) and marketed drug product (tablet) (filled squares); upper right: accumulative release of oleanolic acid. Reproduced from [151] with permission

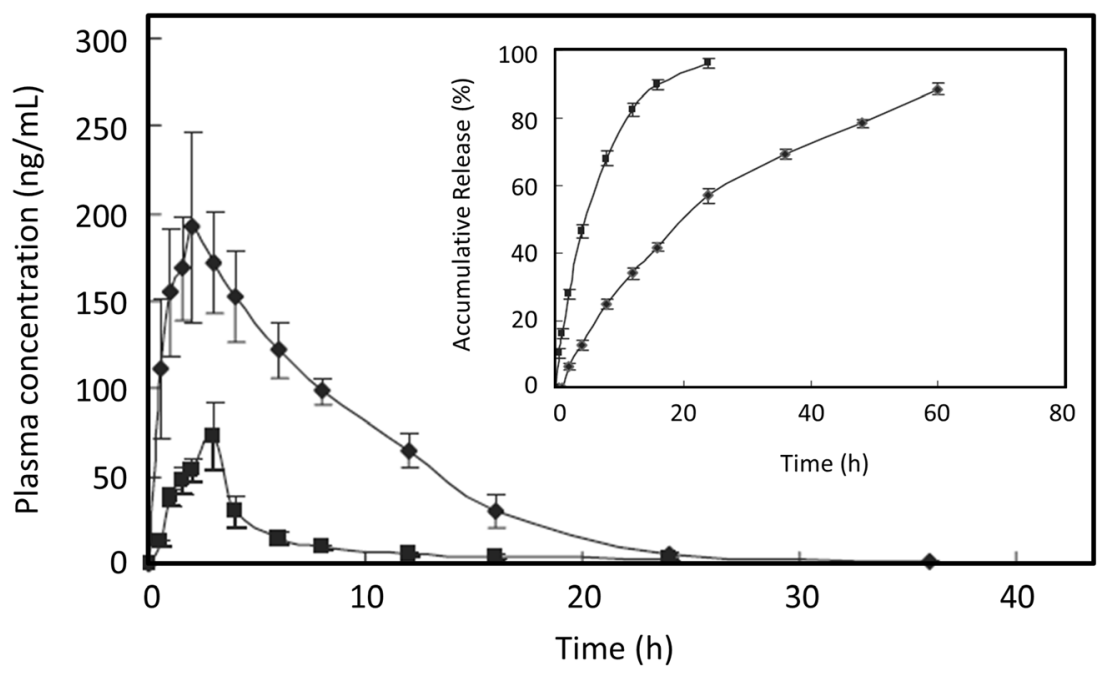

of chito-oligosaccharide. In vivo pharmacokinetics showed a significant increase in Flos Lonicerae Japonicae and Fructus forsythia concentrations when co-delivered with chito-oligosaccharide, relative to herb administration alone (Fig. 5a). In addition, enhanced antiviral effect was achieved in four preparations containing chito-oligosaccharide, which was explained by the higher absorption of caffeic acid derivatives (Fig. 5b). This work was unique because it studied the effects of the delivery system on both the pharmacokinetic properties and the antiviral activity of the herbal drug, directly.

An inclusion complex of honokiol and sulfobutyl ether- $\beta$ cyclodextrin was made to enhance the solubility and bioavailability of the herbal drug [148]. In a phase solubility experiment, honokiol solubility linearly increased with growing levels of the cyclodextrin. The in vitro release study showed that the honokiol/cyclodextrin complex allowed enhanced release rate than either honokiol/cyclodextrin physical mixture or honokiol alone. In rat oral pharmacokinetics, AUC and $C_{\max }$ values of the inclusion complex were 1.58 and 1.23 times higher relative to honokiol suspension, respectively.

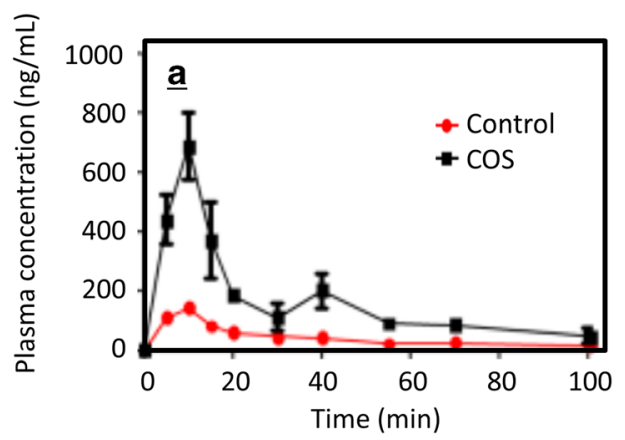

Fig. 5 Effect of COS (chito-oligosaccharide) on the pharmacokinetic (panel a) and pharmacodynamics (inhibition of influenza virus; panel b) of caffeic acid derivative after oral administration of preparation containing Flos Lonicerae Japonicae and Fructus, forsythia extracts. Black, 1:1:2-fold of Flos Lonicerae Japonicae, Fructus Forsythiae, and Radix Scutellariae, respectively; red, only Radix Scutellariae; green,
Also, honokiol in suspension had 3 times higher body clearance than complexed honokiol.

Andrographolide is sparingly soluble in water, unstable in very acidic and basic conditions, poorly absorbed, and has low oral bioavailability. PLGA (poly(lactic-co-glycolic acid)) was used to form andrographolide loaded microspheres to overcome these limitations [124]. In vitro andrographolidemicrosphere formulation exhibited sustained release profile over 9 days, with just $14 \%$ andrographolide release over the first $8 \mathrm{~h}$, because of low drug density at the surface of the delivery system, which also allowed a relatively high oral bioavailability of $67.5 \%$. Lastly, fine correlation was obtained between in vitro drug release and in vivo absorption, indicating that the in vitro assay may be a good predictor of drug absorption in vivo.

Curcumin, a polyphenolic compound with various medical applications including known antivirus activity, is poorly watersoluble and has low oral bioavailability. With N-acetyl L-cysteine and different levels $(20,50$, and $100 \mathrm{mg})$ of polyethylene glycol (PEG), nanostructured solid lipid carriers were synthesized to obtain curcumin mucoadhesion and mucus penetration

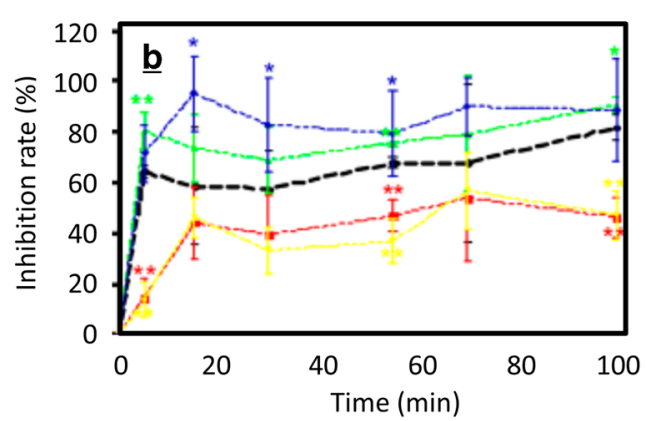

2:2:2-fold of Flos Lonicerae Japonicae, Fructus Forsythiae, and Radix Scutellariae, respectively; yellow, COS with added Radix Scutellariae only; blue, COS with added 1:1:2-fold of Flos Lonicerae Japonicae, Fructus Forsythiae, and Radix Scutellariae, respectively $(n=6)$. Reproduced from [122] with permission 
[156]. Drug release was characterized in vitro for curcumin solution, curcumin-loaded nanolipid carrier, and curcumin-loaded nanolipid carrier with $\mathrm{N}$-acetyl L-cysteine PEG. From the curcumin solution, $80 \%$ of drug was released after $4 \mathrm{~h}$, whereas all the nanolipid formulations allowed sustained curcumin release; the sustained release effect from the modified nanolipid carriers was more pronounced than that of unmodified nanolipids. An SPIP study in rats was then conducted, and results were similar for all three parts of the small intestine: nanolipids allowed enhanced curcumin permeation relative to solution, and so did higher $\mathrm{N}$-acetyl L-cysteine content. Pharmacokinetic study of curcumin solutions (P.O and I.V) and curcumin nanolipid carriers (with $\mathrm{N}$-acetyl L-cysteine PEG content of 0,20,50, and $100 \mathrm{mg}$ ) was conducted. Similar to the results of the permeability experiment, plasma curcumin concentrations were higher with nanolipid carriers relative to solution (either P.O or I.V) and increased further with higher N-acetyl Lcysteine PEG levels. The area under the curve was substantially larger with the modified nanolipid carriers compared to either curcumin solution or to the unmodified delivery system.

Indeed, modern drug delivery technologies are numerous, and tailoring the most appropriate formulation to the medicinal phytochemical in question is not just a matter of trial and error; rather, the physicochemical properties of the specific natural drug substance determine the delivery issues that the formulator may face, and the excipients that can be used to overcome these challenges $[157,158]$. Among the physicochemical properties of importance are $\log$ P (a measure of the drug's lipophilicity) and melting point. These parameters will determine the likelihood of the active substance to precipitate in the gastrointestinal lumen, in which case the use of amorphous formulations may be preferred over other oral carriers. Additional important physicochemical properties include the drug's chemical structure and molecular weight; using previously successful formulations to deliver drugs with similar chemical structure may be a wise approach. Also, generally speaking, higher molecular weight substances may be better incorporated into lipid-based drug delivery systems [159-161]. It should be noted that some solubility-enabling formulations may simultaneously decrease the drug's permeability, and overall absorption may be unimproved. This solubilitypermeability interplay was shown for formulations based on cyclodextrins [162-164], surfactants [165], cosolvents [166], and hydrotropes [167, 168]. In amorphous solid dispersions (ASD), on the other hand, the solubility increases (via supersaturation) with unchanged permeability, and thus, ASD may be preferred over other carrier systems, given supersaturation can be achieved and maintained for sufficient time [169].

\section{Conclusions}

Altogether, the evidence presented in this work supports the notion that medicinal plants have promising therapeutic potential, especially in the case of herb products against viral infections. Further research on the mechanisms by which phytochemicals exhibit their antiviral effect will allow the developing of successful target-specific drug delivery systems. At the moment, we cannot ensure the plant phytochemicals directly reach viruses or the correct structures inside cells. Ideally, we would have smart pharmaceutical nanotechnologies and targeting strategies that can avoid cellular defenses, transport drugs to targeted intracellular sites, and release the drugs in response to specific molecular signals. Literature also lacks randomized clinical trials to discern the strength of new herbal antiviral drug delivery systems. It is our hope that in the future more high quality clinically relevant studies will accumulate in the literature, which will shed light on the full potential of phytochemicals as novel antiviral agents in adequate delivery systems.

\section{Compliance with ethical standards}

Conflict of interest The authors declare that they have no conflict of interest.

\section{References}

1. Gasparini R, Amicizia D, Lai PL, Panatto D. Clinical and socioeconomic impact of seasonal and pandemic influenza in adults and the elderly. Hum Vaccin Immunother. 2012;8(1):21-8. https://doi. org/10.4161/hv.8.1.17622.

2. Novakova L, Pavlik J, Chrenkova L, Martinec O, Cerveny L. Current antiviral drugs and their analysis in biological materials - part II: antivirals against hepatitis and HIV viruses. J Pharm Biomed Anal. 2018;147:378-99. https://doi.org/10.1016/j.jpba. 2017.07.003.

3. Soltan MM, Zaki AK. Antiviral screening of forty-two Egyptian medicinal plants. J Ethnopharmacol. 2009;126(1):102-7. https:// doi.org/10.1016/j.jep.2009.08.001.

4. Brijesh S, Daswani P, Tetali P, Antia N, Birdi T. Studies on the antidiarrhoeal activity of Aegle marmelos unripe fruit: validating its traditional usage. BMC Complement Altern Med. 2009;9:47. https://doi.org/10.1186/1472-6882-9-47.

5. Moradi MT, Rafieian-Kopaei M, Karimi A. A review study on the effect of Iranian herbal medicines against in vitro replication of herpes simplex virus. Avicenna J Phytomed. 2016;6(5):506-15.

6. Goncalves JL, Lopes RC, Oliveira DB, Costa SS, Miranda MM, Romanos MT, et al. In vitro anti-rotavirus activity of some medicinal plants used in Brazil against diarrhea. J Ethnopharmacol. 2005;99(3):403-7. https://doi.org/10.1016/j.jep.2005.01.032.

7. Maregesi SM, Pieters L, Ngassapa OD, Apers S, Vingerhoets R, Cos $\mathrm{P}$, et al. Screening of some Tanzanian medicinal plants from Bunda district for antibacterial, antifungal and antiviral activities. J Ethnopharmacol. 2008;119(1):58-66. https://doi.org/10.1016/j. jep.2008.05.033.

8. Karamese M, Aydogdu S, Karamese SA, Altoparlak U, Gundogdu C. Preventive effects of a major component of green tea, epigallocathechin-3-gallate, on hepatitis-B virus DNA replication. Asian Pac J Cancer Prev. 2015;16(10):4199-202.

9. Lam SK, Ng TB. A protein with antiproliferative, antifungal and HIV-1 reverse transcriptase inhibitory activities from caper 
(Capparis spinosa) seeds. Phytomedicine. 2009;16(5):444-50. https://doi.org/10.1016/j.phymed.2008.09.006.

10. Callies O, Bedoya LM, Beltran M, Munoz A, Calderon PO, Osorio AA, et al. Isolation, structural modification, and HIV inhibition of pentacyclic lupane-type triterpenoids from Cassine xylocarpa and Maytenus cuzcoina. J Nat Prod. 2015;78(5): 1045-55. https://doi.org/10.1021/np501025r.

11. Droebner K, Ehrhardt C, Poetter A, Ludwig S, Planz O. CYSTUS052, a polyphenol-rich plant extract, exerts antiinfluenza virus activity in mice. Antiviral Res. 2007;76(1):1-10. https://doi.org/10.1016/j.antiviral.2007.04.001.

12. Ehrhardt C, Hrincius ER, Korte V, Mazur I, Droebner K, Poetter A, et al. A polyphenol rich plant extract, CYSTUS052, exerts anti influenza virus activity in cell culture without toxic side effects or the tendency to induce viral resistance. Antiviral Res. 2007;76(1): 38-47. https://doi.org/10.1016/j.antiviral.2007.05.002.

13. Rebensburg S, Helfer M, Schneider M, Koppensteiner H, Eberle J, Schindler M, et al. Potent in vitro antiviral activity of Cistus incanus extract against HIV and Filoviruses targets viral envelope proteins. Sci Rep. 2016;6:20394. https://doi.org/10.1038/ srep20394.

14. Xu HB, Ma YB, Huang XY, Geng CA, Wang H, Zhao Y, et al. Bioactivity-guided isolation of anti-hepatitis $B$ virus active sesquiterpenoids from the traditional Chinese medicine: rhizomes of Cyperus rotundus. J Ethnopharmacol. 2015;171:131-40. https://doi.org/10.1016/j.jep.2015.05.040.

15. Vidal V, Potterat O, Louvel S, Hamy F, Mojarrab M, Sanglier JJ, et al. Library-based discovery and characterization of daphnane diterpenes as potent and selective HIV inhibitors in Daphne gnidium. J Nat Prod. 2012;75(3):414-9. https://doi.org/10.1021/ np200855d.

16. Abad MJ, Guerra JA, Bermejo P, Irurzun A, Carrasco L. Search for antiviral activity in higher plant extracts. Phytother Res. 2000;14(8):604-7.

17. Gyuris A, Szlavik L, Minarovits J, Vasas A, Molnar J, Hohmann J. Antiviral activities of extracts of Euphorbia hirta L. against HIV-1, HIV-2 and SIVmac251. In Vivo. 2009;23(3):429-32.

18. Yarmolinsky L, Huleihel M, Zaccai M, Ben-Shabat S. Potent antiviral flavone glycosides from Ficus benjamina leaves. Fitoterapia. 2012;83(2):362-7. https://doi.org/10.1016/j.fitote. 2011.11.014

19. Wang G, Wang H, Song Y, Jia C, Wang Z, Xu H. Studies on antiHSV effect of Ficus carica leaves. Zhong Yao Cai. 2004;27(10): 754-6.

20. Lazreg Aref H, Gaaliche B, Fekih A, Mars M, Aouni M, Pierre Chaumon J, et al. In vitro cytotoxic and antiviral activities of Ficus carica latex extracts. Nat Prod Res. 2011;25(3):310-9. https://doi. org/10.1080/14786419.2010.528758.

21. Asl Najjari AH, Rajabi Z, Vasfi Marandi M, Dehghan G. The effect of the hexanic extracts of fig (Ficus carica) and olive (Olea europaea) fruit and nanoparticles of selenium on the immunogenicity of the inactivated avian influenza virus subtype H9N2. Vet Res Forum. 2015;6(3):227-31.

22. Ashraf A, Ashraf MM, Rafiqe A, Aslam B, Galani S, Zafar S, et al. In vivo antiviral potential of Glycyrrhiza glabra extract against Newcastle disease virus. Pak J Pharm Sci. 2017;30(2 Suppl):567-72.

23. Alfajaro MM, Kim HJ, Park JG, Ryu EH, Kim JY, Jeong YJ, et al. Anti-rotaviral effects of Glycyrrhiza uralensis extract in piglets with rotavirus diarrhea. Virol J. 2012;9:310. https://doi.org/10. 1186/1743-422X-9-310.

24. Szlavik L, Gyuris A, Minarovits J, Forgo P, Molnar J, Hohmann J. Alkaloids from Leucojum vernum and antiretroviral activity of Amaryllidaceae alkaloids. Planta Med. 2004;70(9):871-3. https://doi.org/10.1055/s-2004-827239.
25. Yarmolinsky L, Zaccai M, Ben-Shabat S, Mills D, Huleihel M. Antiviral activity of ethanol extracts of Ficus binjamina and Lilium candidum in vitro. N Biotechnol. 2009;26(6):307-13. https://doi.org/10.1016/j.nbt.2009.08.005.

26. Fang CY, Chen SJ, Wu HN, Ping YH, Lin CY, Shiuan D, et al. Honokiol, a lignan biphenol derived from the Magnolia Tree, inhibits dengue virus type 2 infection. Viruses. 2015;7(9):4894-910. https://doi.org/10.3390/v7092852.

27. Astani A, Reichling J, Schnitzler P. Melissa officinalis extract inhibits attachment of herpes simplex virus in vitro. Chemotherapy. 2012;58(1):70-7. https://doi.org/10.1159/ 000335590.

28. Nolkemper S, Reichling J, Stintzing FC, Carle R, Schnitzler P. Antiviral effect of aqueous extracts from species of the Lamiaceae family against Herpes simplex virus type 1 and type 2 in vitro. Planta Med. 2006;72(15):1378-82. https://doi.org/10. 1055/s-2006-951719.

29. Geuenich S, Goffinet C, Venzke S, Nolkemper S, Baumann I, Plinkert $\mathrm{P}$, et al. Aqueous extracts from peppermint, sage and lemon balm leaves display potent anti-HIV-1 activity by increasing the virion density. Retrovirology. 2008;5:27. https://doi.org/ 10.1186/1742-4690-5-27.

30. Parsania M, Rezaee MB, Monavari SH, Jaimand K, MousaviJazayeri SM, Razazian M, et al. Antiviral screening of four plant extracts against acyclovir resistant herpes simplex virus type-1. Pak J Pharm Sci. 2017;30(4 Suppl):1407-11.

31. Choi JG, Jin YH, Lee H, Oh TW, Yim NH, Cho WK, et al. Protective effect of Panax notoginseng root water extract against influenza A virus infection by enhancing antiviral interferon-mediated immune responses and natural killer cell activity. Front Immunol. 2017;8: 1542. https://doi.org/10.3389/fimmu.2017.01542.

32. Lv JJ, Yu S, Wang YF, Wang D, Zhu HT, Cheng RR, et al. Antihepatitis B virus norbisabolane sesquiterpenoids from Phyllanthus acidus and the establishment of their absolute configurations using theoretical calculations. J Org Chem. 2014;79(12):5432-47. https://doi.org/10.1021/jo5004604.

33. Lv JJ, Yu S, Xin Y, Cheng RR, Zhu HT, Wang D, et al. Anti-viral and cytotoxic norbisabolane sesquiterpenoid glycosides from Phyllanthus emblica and their absolute configurations. Phytochemistry. 2015;117:123-34. https://doi.org/10.1016/j. phytochem.2015.06.001.

34. Lv JJ, Wang YF, Zhang JM, Yu S, Wang D, Zhu HT, et al. Antihepatitis B virus activities and absolute configurations of sesquiterpenoid glycosides from Phyllanthus emblica. Org Biomol Chem. 2014;12(43):8764-74. https://doi.org/10.1039/ c4ob01196a.

35. Oh C, Price J, Brindley MA, Widrlechner MP, Qu L, McCoy JA, et al. Inhibition of HIV-1 infection by aqueous extracts of Prunella vulgaris L. Virol J. 2011;8:188. https://doi.org/10.1186/1743422X-8-188.

36. Zhang X, Ao Z, Bello A, Ran X, Liu S, Wigle J, et al. Characterization of the inhibitory effect of an extract of Prunella vulgaris on Ebola virus glycoprotein (GP)-mediated virus entry and infection. Antiviral Res. 2016;127:20-31. https://doi.org/10. 1016/j.antiviral.2016.01.001.

37. Karimi A, Rafieian-Kopaei M, Moradi MT, Alidadi S. Anti-herpes simplex virus type- 1 activity and phenolic content of crude ethanol extract and four corresponding fractions of Quercus brantii L Acorn. J Evid Based Complementary Altern Med. 2016;22(3): 455-61. https://doi.org/10.1177/2156587216676421.

38. Karimi A, Moradi MT, Saeedi M, Asgari S, Rafieian-Kopaei M. Antiviral activity of Quercus persica L.: high efficacy and low toxicity. Adv Biomed Res. 2013;2:36. https://doi.org/10.4103/ 2277-9175.109722.

39. Romero-Perez GA, Egashira M, Harada Y, Tsuruta T, Oda Y, Ueda F, et al. Orally administered Salacia reticulata extract reduces 
H1N1 influenza clinical symptoms in murine lung tissues putatively due to enhanced natural killer cell activity. Front Immunol. 2016;7:115. https://doi.org/10.3389/fimmu.2016.00115.

40. Bedoya LM, Sanchez-Palomino S, Abad MJ, Bermejo P, Alcami J. Anti-HIV activity of medicinal plant extracts. J Ethnopharmacol. 2001;77(1):113-6.

41. Javed T, Ashfaq UA, Riaz S, Rehman S, Riazuddin S. In-vitro antiviral activity of Solanum nigrum against hepatitis $\mathrm{C}$ virus. Virol J. 2011;8:26. https://doi.org/10.1186/1743-422X-8-26.

42. Rehman S, Ijaz B, Fatima N, Muhammad SA, Riazuddin S. Therapeutic potential of Taraxacum officinale against HCV NS5B polymerase: in-vitro and In silico study. Biomed Pharmacother. 2016;83:881-91. https://doi.org/10.1016/j.biopha. 2016.08.002.

43. He W, Han H, Wang W, Gao B. Anti-influenza virus effect of aqueous extracts from dandelion. Virol J. 2011;8:538. https://doi. org/10.1186/1743-422X-8-538.

44. Soleimani Farsani M, Behbahani M, Isfahani HZ. The effect of root, shoot and seed extracts of the Iranian Thymus L. (Family: Lamiaceae) species on HIV-1 replication and CD4 expression. Cell J. 2016;18(2):255-61.

45. Bedoya LM, Abad MJ, Sanchez-Palomino S, Alcami J, Bermejo P. Ellagitannins from Tuberaria lignosa as entry inhibitors of HIV. Phytomedicine. 2010;17(1):69-74. https://doi.org/10.1016/j. phymed.2009.08.008.

46. Dai JJ, Tao HM, Min QX, Zhu QH. Anti-hepatitis B virus activities of friedelolactones from Viola diffusa Ging. Phytomedicine. 2015;22(7-8):724-9. https://doi.org/10.1016/j.phymed.2015.05. 001 .

47. Arabzadeh AM, Ansari-Dogaheh M, Sharififar F, Shakibaie M, Heidarbeigi M. Anti herpes simplex-1 activity of a standard extract of Zataria multiflora Boiss. Pak J Biol Sci. 2013;16(4):180-4.

48. Ibrahim AK, Youssef AI, Arafa AS, Ahmed SA. Anti-H5N1 virus flavonoids from Capparis sinaica Veill. Nat Prod Res. 2013;27(22):2149-53. https://doi.org/10.1080/14786419.2013. 790027.

49. Orhan DD, Ozcelik B, Ozgen S, Ergun F. Antibacterial, antifungal, and antiviral activities of some flavonoids. Microbiol Res. 2010;165(6):496-504. https://doi.org/10.1016/j.micres.2009.09. 002 .

50. Wu W, Li R, Li X, He J, Jiang S, Liu S, et al. Quercetin as an antiviral agent inhibits influenza A virus (IAV) entry. Viruses. 2015;8(1):E6. https://doi.org/10.3390/v8010006.

51. Ganesan S, Faris AN, Comstock AT, Wang Q, Nanua S, Hershenson MB, et al. Quercetin inhibits rhinovirus replication in vitro and in vivo. Antiviral Res. 2012;94(3):258-71. https://doi. org/10.1016/j.antiviral.2012.03.005.

52. Zandi K, Teoh BT, Sam SS, Wong PF, Mustafa MR, Abubakar S. Antiviral activity of four types of bioflavonoid against dengue virus type-2. Virol J. 2011;8:560. https://doi.org/10.1186/1743$422 \mathrm{X}-8-560$

53. Chiang LC, Chiang W, Liu MC, Lin CC. In vitro antiviral activities of Caesalpinia pulcherrima and its related flavonoids. J Antimicrob Chemother. 2003;52(2):194-8. https://doi.org/10. 1093/jac/dkg291.

54. Neznanov N, Kondratova A, Chumakov KM, Neznanova L, Kondratov R, Banerjee AK, et al. Quercetinase pirin makes poliovirus replication resistant to flavonoid quercetin. DNA Cell Biol. 2008;27(4):191-8. https://doi.org/10.1089/dna.2007.0682.

55. Lee M, Son M, Ryu E, Shin YS, Kim JG, Kang BW, et al. Quercetin-induced apoptosis prevents EBV infection. Oncotarget. 2015;6(14):12603-24. https://doi.org/10.18632/ oncotarget.3687.

56. dos Santos AE, Kuster RM, Yamamoto KA, Salles TS, Campos R, de Meneses MD, et al. Quercetin and quercetin 3-O-glycosides from Bauhinia longifolia (Bong.) Steud. show anti-Mayaro virus activity. Parasit Vectors. 2014;7:130. https://doi.org/10.1186/ 1756-3305-7-130.

57. Johari J, Kianmehr A, Mustafa MR, Abubakar S, Zandi K. Antiviral activity of baicalein and quercetin against the Japanese encephalitis virus. Int J Mol Sci. 2012;13(12):16785-95. https:// doi.org/10.3390/ijms131216785.

58. Li YL, Li KM, Su MX, Leung KT, Chen YW, Zhang YW. Studies on antiviral constituents in stems and leaves of Pithecellibium clypearia. Zhongguo Zhong Yao Za Zhi. 2006;31(5):397-400.

59. Bachmetov L, Gal-Tanamy M, Shapira A, Vorobeychik M, Giterman-Galam T, Sathiyamoorthy P, et al. Suppression of hepatitis $\mathrm{C}$ virus by the flavonoid quercetin is mediated by inhibition of NS3 protease activity. J Viral Hepat. 2012;19(2):e81-8. https:// doi.org/10.1111/j.1365-2893.2011.01507.x.

60. Gonzalez O, Fontanes V, Raychaudhuri S, Loo R, Loo J, Arumugaswami $\mathrm{V}$, et al. The heat shock protein inhibitor Quercetin attenuates hepatitis C virus production. Hepatology. 2009;50(6):1756-64. https://doi.org/10.1002/hep.23232.

61. Nakane H, Ono K. Differential inhibitory effects of some catechin derivatives on the activities of human immunodeficiency virus reverse transcriptase and cellular deoxyribonucleic and ribonucleic acid polymerases. Biochemistry. 1990;29(11):2841-5.

62. Park S, Kim JI, Lee I, Lee S, Hwang MW, Bae JY, et al. Aronia melanocarpa and its components demonstrate antiviral activity against influenza viruses. Biochem Biophys Res Commun. 2013;440(1):14-9. https://doi.org/10.1016/j.bbrc.2013.08.090.

63. Zhang W, Qiao H, Lv Y, Wang J, Chen X, Hou Y, et al. Apigenin inhibits enterovirus-71 infection by disrupting viral RNA association with trans-acting factors. PLoS One. 2014;9(10):e110429. https://doi.org/10.1371/journal.pone.0110429.

64. Qian S, Fan W, Qian P, Zhang D, Wei Y, Chen H, et al. Apigenin restricts FMDV infection and inhibits viral IRES driven translational activity. Viruses. 2015;7(4):1613-26. https://doi.org/10. 3390/v7041613.

65. Shibata C, Ohno M, Otsuka M, Kishikawa T, Goto K, Muroyama $\mathrm{R}$, et al. The flavonoid apigenin inhibits hepatitis $\mathrm{C}$ virus replication by decreasing mature microRNA122 levels. Virology. 2014;462-463:42-8. https://doi.org/10.1016/j.virol.2014.05.024.

66. Hakobyan A, Arabyan E, Avetisyan A, Abroyan L, Hakobyan L, Zakaryan H. Apigenin inhibits African swine fever virus infection in vitro. Arch Virol. 2016;161(12):3445-53. https://doi.org/10. 1007/s00705-016-3061-y.

67. Sithisarn P, Michaelis M, Schubert-Zsilavecz M, Cinatl J Jr. Differential antiviral and anti-inflammatory mechanisms of the flavonoids biochanin A and baicalein in H5N1 influenza A virus-infected cells. Antiviral Res. 2013;97(1):41-8. https://doi. org/10.1016/j.antiviral.2012.10.004.

68. Li X, Liu Y, Wu T, Jin Y, Cheng J, Wan C, et al. The antiviral effect of baicalin on enterovirus 71 in vitro. Viruses. 2015;7(8):4756-71. https://doi.org/10.3390/v7082841.

69. Moghaddam E, Teoh BT, Sam SS, Lani R, Hassandarvish P, Chik Z, et al. Baicalin, a metabolite of baicalein with antiviral activity against dengue virus. Sci Rep. 2014;4:5452. https://doi.org/10. 1038/srep05452.

70. Shi H, Ren K, Lv B, Zhang W, Zhao Y, Tan RX, et al. Baicalin from Scutellaria baicalensis blocks respiratory syncytial virus (RSV) infection and reduces inflammatory cell infiltration and lung injury in mice. Sci Rep. 2016;6:35851. https://doi.org/10. 1038/srep35851.

71. Jia Y, Xu R, Hu Y, Zhu T, Ma T, Wu H, et al. Anti-NDV activity of baicalin from a traditional Chinese medicine in vitro. J Vet Med Sci. 2016;78(5):819-24. https://doi.org/10.1292/jvms.15-0572.

72. Li BQ, Fu T, Dongyan Y, Mikovits JA, Ruscetti FW, Wang JM. Flavonoid baicalin inhibits HIV-1 infection at the level of viral entry. Biochem Biophys Res Commun. 2000;276(2):534-8. https://doi.org/10.1006/bbrc.2000.3485. 
73. Huang H, Zhou W, Zhu H, Zhou P, Shi X. Baicalin benefits the anti-HBV therapy via inhibiting HBV viral RNAs. Toxicol Appl Pharmacol. 2017;323:36-43. https://doi.org/10.1016/j.taap.2017. 03.016.

74. Kong L, Li S, Liao Q, Zhang Y, Sun R, Zhu X, et al. Oleanolic acid and ursolic acid: novel hepatitis $\mathrm{C}$ virus antivirals that inhibit NS5B activity. Antiviral Res. 2013;98(1):44-53. https://doi.org/ 10.1016/j.antiviral.2013.02.003.

75. Zhao $\mathrm{CH}, \mathrm{Xu}$ J, Zhang YQ, Zhao LX, Feng B. Inhibition of human enterovirus 71 replication by pentacyclic triterpenes and their novel synthetic derivatives. Chem Pharm Bull (Tokyo). 2014;62(8):764-71.

76. Zakay-Rones Z, Varsano N, Zlotnik M, Manor O, Regev L, Schlesinger M, et al. Inhibition of several strains of influenza virus in vitro and reduction of symptoms by an elderberry extract (Sambucus nigra L.) during an outbreak of influenza B Panama. J Altern Complement Med. 1995;1(4):361-9. https://doi.org/10. 1089/acm.1995.1.361.

77. Krawitz C, Mraheil MA, Stein M, Imirzalioglu C, Domann E, Pleschka S, et al. Inhibitory activity of a standardized elderberry liquid extract against clinically relevant human respiratory bacterial pathogens and influenza A and B viruses. BMC Complement Altern Med. 2011;11:16. https://doi.org/10.1186/1472-6882-1116.

78. Zakay-Rones Z, Thom E, Wollan T, Wadstein J. Randomized study of the efficacy and safety of oral elderberry extract in the treatment of influenza A and B virus infections. J Int Med Res. $2004 ; 32$ (2):132-40. https://doi.org/10.1177/ 147323000403200205 .

79. Qian J, Meng H, Xin L, Xia M, Shen H, Li G, et al. Selfnanoemulsifying drug delivery systems of myricetin: formulation development, characterization, and in vitro and in vivo evaluation. Colloids Surf B Biointerfaces. 2017;160:101-9. https://doi.org/ 10.1016/j.colsurfb.2017.09.020.

80. Yao Y, Xia M, Wang H, Li G, Shen H, Ji G, et al. Preparation and evaluation of chitosan-based nanogels/gels for oral delivery of myricetin. Eur J Pharm Sci. 2016;91:144-53. https://doi.org/10. 1016/j.ejps.2016.06.014.

81. Tang XJ, Huang KM, Gui H, Wang JJ, Lu JT, Dai LJ, et al. Pluronic-based micelle encapsulation potentiates myricetininduced cytotoxicity in human glioblastoma cells. Int $\mathrm{J}$ Nanomedicine. 2016;11:4991-5002. https://doi.org/10.2147/IJN. S114302.

82. Hong C, Dang Y, Lin G, Yao Y, Li G, Ji G, et al. Effects of stabilizing agents on the development of myricetin nanosuspension and its characterization: an in vitro and in vivo evaluation. Int J Pharm. 2014;477(1-2):251-60. https://doi.org/10. 1016/j.ijpharm.2014.10.044

83. Hong C, Xie Y, Yao Y, Li G, Yuan X, Shen H. A novel strategy for pharmaceutical cocrystal generation without knowledge of stoichiometric ratio: myricetin cocrystals and a ternary phase diagram. Pharm Res. 2015;32(1):47-60. https://doi.org/10.1007/s11095014-1443-y.

84. Chakraborty S, Basu S, Basak S. Effect of beta-cyclodextrin on the molecular properties of myricetin upon nano-encapsulation: insight from optical spectroscopy and quantum chemical studies. Carbohydr Polym. 2014;99:116-25. https://doi.org/10.1016/j. carbpol.2013.08.008.

85. Kim BK, Cho AR, Park DJ. Enhancing oral bioavailability using preparations of apigenin-loaded $\mathrm{W} / \mathrm{O} / \mathrm{W}$ emulsions: in vitro and in vivo evaluations. Food Chem. 2016;206:85-91. https://doi.org/ 10.1016/j.foodchem.2016.03.052.

86. Zhao X, Wang Z. A pH-sensitive microemulsion-filled gellan gum hydrogel encapsulated apigenin: Characterization and in vitro release kinetics. Colloids Surf B Biointerfaces. 2019;178:245-52. https://doi.org/10.1016/j.colsurfb.2019.03.015.
87. Alshehri SM, Shakeel F, Ibrahim MA, Elzayat EM, Altamimi M, Mohsin K, et al. Dissolution and bioavailability improvement of bioactive apigenin using solid dispersions prepared by different techniques. Saudi Pharm J. 2019;27(2):264-73. https://doi.org/ 10.1016/j.jsps.2018.11.008.

88. Ding SM, Zhang ZH, Song J, Cheng XD, Jiang J, Jia XB. Enhanced bioavailability of apigenin via preparation of a carbon nanopowder solid dispersion. Int J Nanomedicine. 2014;9:232733. https://doi.org/10.2147/IJN.S60938.

89. Zhang Z, Cui C, Wei F, Lv H. Improved solubility and oral bioavailability of apigenin via Soluplus/Pluronic F127 binary mixed micelles system. Drug Dev Ind Pharm. 2017;43(8):1276-82. https://doi.org/10.1080/03639045.2017.1313857.

90. Telange DR, Patil AT, Pethe AM, Fegade H, Anand S, Dave VS. Formulation and characterization of an apigenin-phospholipid phytosome (APLC) for improved solubility, in vivo bioavailability, and antioxidant potential. Eur J Pharm Sci. 2017;108:36-49. https://doi.org/10.1016/j.ejps.2016.12.009.

91. Papay ZE, Kallai-Szabo N, Balogh E, Ludanyi K, Klebovich I, Antal I. Controlled release oral delivery of apigenin containing pellets with antioxidant activity. Curr Drug Deliv. 2017;14(1): 145-54. https://doi.org/10.2174/1567201813666160602193047.

92. Zhao L, Zhang L, Meng L, Wang J, Zhai G. Design and evaluation of a self-microemulsifying drug delivery system for apigenin. Drug Dev Ind Pharm. 2013;39(5):662-9. https://doi.org/10.3109/ 03639045.2012.687378.

93. Wei Y, Guo J, Zheng X, Wu J, Zhou Y, Yu Y, et al. Preparation, pharmacokinetics and biodistribution of baicalin-loaded liposomes. Int J Nanomedicine. 2014;9:3623-30. https://doi.org/10. 2147/IJN.S66312.

94. Zhang H, Yang X, Zhao L, Jiao Y, Liu J, Zhai G. In vitro and in vivo study of Baicalin-loaded mixed micelles for oral delivery. Drug Deliv. 2016;23(6):1933-9. https://doi.org/10.3109/ 10717544.2015.1008705.

95. Zhang H, Zhao L, Chu L, Han X, Zhai G. Preparation, optimization, characterization and cytotoxicity in vitro of baicalin-loaded mixed micelles. J Colloid Interface Sci. 2014;434:40-7. https:// doi.org/10.1016/j.jcis.2014.07.045.

96. Liu X, Chen Y, Chen X, Su J, Huang C. Enhanced efficacy of baicalin-loaded TPGS polymeric micelles against periodontitis. Mater Sci Eng C Mater Biol Appl. 2019;101:387-95. https://doi. org/10.1016/j.msec.2019.03.103.

97. Jakab G, Fulop V, Bozo T, Balogh E, Kellermayer M, Antal I. Optimization of quality attributes and atomic force microscopy imaging of reconstituted nanodroplets in baicalin loaded selfnanoemulsifying formulations. Pharmaceutics. 2018;10(4):E275. https://doi.org/10.3390/pharmaceutics10040275.

98. Wu L, Bi Y, Wu H. Formulation optimization and the absorption mechanisms of nanoemulsion in improving baicalin oral exposure. Drug Dev Ind Pharm. 2018;44(2):266-75. https://doi.org/ 10.1080/03639045.2017.1391831.

99. Li J, Jiang Q, Deng P, Chen Q, Yu M, Shang J, et al. The formation of a host-guest inclusion complex system between betacyclodextrin and baicalin and its dissolution characteristics. J Pharm Pharmacol. 2017;69(6):663-74. https://doi.org/10.1111/ jphp.12708.

100. Cui L, Sune E, Song J, Wang J, Jia XB, Zhang ZH. Characterization and bioavailability study of baicalinmesoporous carbon nanopowder solid dispersion. Pharmacogn Mag. 2016;12(48):326-32. https://doi.org/10.4103/0973-1296. 192199.

101. Liu Z, Zhao H, Shu L, Zhang Y, Okeke C, Zhang L, et al. Preparation and evaluation of Baicalin-loaded cationic solid lipid nanoparticles conjugated with OX26 for improved delivery across the BBB. Drug Dev Ind Pharm. 2015;41(3):353-61. https://doi. org/10.3109/03639045.2013.861478. 
102. Shi-Ying J, Jin H, Shi-Xiao J, Qing-Yuan L, Jin-Xia B, Chen HG, et al. Characterization and evaluation in vivo of baicalinnanocrystals prepared by an ultrasonic-homogenization-fluid bed drying method. Chin J Nat Med. 2014;12(1):71-80. https://doi. org/10.1016/S1875-5364(14)60012-1.

103. Zhang J, Lv H, Jiang K, Gao Y. Enhanced bioavailability after oral and pulmonary administration of baicalein nanocrystal. Int $\mathrm{J}$ Pharm. 2011;420(1):180-8. https://doi.org/10.1016/j.ijpharm. 2011.08.023.

104. Liu W, Tian R, Hu W, Jia Y, Jiang H, Zhang J, et al. Preparation and evaluation of self-microemulsifying drug delivery system of baicalein. Fitoterapia. 2012;83(8):1532-9. https://doi.org/10. 1016/j.fitote.2012.08.021.

105. Lai F, Franceschini I, Corrias F, Sala MC, Cilurzo F, Sinico C, et al. Maltodextrin fast dissolving films for quercetin nanocrystal delivery. A feasibility study. Carbohydr Polym. 2015;121:217-23. https://doi.org/10.1016/j.carbpol.2014.11.070.

106. Aluani D, Tzankova V, Kondeva-Burdina M, Yordanov Y, Nikolova E, Odzhakov F, et al. Capital IE, Cyrillic valuation of biocompatibility and antioxidant efficiency of chitosan-alginate nanoparticles loaded with quercetin. Int J Biol Macromol. 2017;103:771-82. https://doi.org/10.1016/j.ijbiomac.2017.05. 062.

107. Anwer MK, Al-Mansoor MA, Jamil S, Al-Shdefat R, Ansari MN, Shakeel F. Development and evaluation of PLGA polymer based nanoparticles of quercetin. Int J Biol Macromol. 2016;92:213-9. https://doi.org/10.1016/j.ijbiomac.2016.07.002.

108. Bagad M, Khan ZA. Poly(n-butylcyanoacrylate) nanoparticles for oral delivery of quercetin: preparation, characterization, and pharmacokinetics and biodistribution studies in Wistar rats. Int $\mathrm{J}$ Nanomedicine. 2015;10:3921-35. https://doi.org/10.2147/IJN. S80706.

109. Barbosa AI, Costa Lima SA, Reis S. Application of pH-responsive fucoidan/chitosan nanoparticles to improve oral quercetin delivery. Molecules. 2019;24(2):E346. https://doi.org/10.3390/ molecules24020346.

110. Sedaghat Doost A, Kassozi V, Grootaert C, Claeys M, Dewettinck K, Van Camp J, et al. Self-assembly, functionality, and in-vitro properties of quercetin loaded nanoparticles based on shellacalmond gum biological macromolecules. Int J Biol Macromol. 2019;129:1024-33. https://doi.org/10.1016/j.ijbiomac.2019.02. 071.

111. Riva A, Ronchi M, Petrangolini G, Bosisio S, Allegrini P. Improved oral absorption of quercetin from quercetin phytosome(R), a new delivery system based on food grade lecithin. Eur J Drug Metab Pharmacokinet. 2019;44(2):169-77. https://doi.org/10.1007/s13318-018-0517-3.

112. Rodriguez EB, Almeda RA, Vidallon MLP, Reyes CT. Enhanced bioactivity and efficient delivery of quercetin through nanoliposomal encapsulation using rice bran phospholipids. J Sci Food Agric. 2019;99(4):1980-9. https://doi.org/10.1002/jsfa. 9396.

113. Lu Z, Bu C, Hu W, Zhang H, Liu M, Lu M, et al. Preparation and in vitro and in vivo evaluation of quercetin-loaded mixed micelles for oral delivery. Biosci Biotechnol Biochem. 2018;82(2):238-46. https://doi.org/10.1080/09168451.2017.1419852.

114. Lv L, Liu C, Li Z, Song F, Li G, Huang X. Pharmacokinetics of quercetin-loaded methoxy poly(ethylene glycol)-b-poly(L-lactic acid) micelle after oral administration in rats. Biomed Res Int. 2017;2017:1750895. https://doi.org/10.1155/2017/1750895.

115. Ahmad N, Ahmad R, Naqvi AA, Alam MA, Abdur Rub R, Ahmad FJ. Enhancement of quercetin oral bioavailability by self-nanoemulsifying drug delivery system and their quantification through ultra high performance liquid chromatography and mass spectrometry in cerebral ischemia. Drug Res (Stuttg). 2017;67(10):564-75. https://doi.org/10.1055/s-0043-109564.
116. Tran TH, Guo Y, Song D, Bruno RS, Lu X. Quercetin-containing self-nanoemulsifying drug delivery system for improving oral bioavailability. J Pharm Sci. 2014;103(3):840-52. https://doi.org/10. 1002/jps.23858.

117. Hadrich G, Monteiro SO, Rodrigues MR, de Lima VR, Putaux JL, Bidone J, et al. Lipid-based nanocarrier for quercetin delivery: system characterization and molecular interactions studies. Drug Dev Ind Pharm. 2016;42(7):1165-73. https://doi.org/10.3109/ 03639045.2015.1118491.

118. Kumar P, Sharma G, Kumar R, Singh B, Malik R, Katare OP, et al. Promises of a biocompatible nanocarrier in improved brain delivery of quercetin: biochemical, pharmacokinetic and biodistribution evidences. Int J Pharm. 2016;515(1-2):307-14. https://doi.org/10.1016/j.ijpharm.2016.10.024.

119. Hadrich G, Vaz GR, Maidana M, Kratz JM, Loch-Neckel G, Favarin DC, et al. Anti-inflammatory effect and toxicology analysis of oral delivery quercetin nanosized emulsion in rats. Pharm Res. 2016;33(4):983-93. https://doi.org/10.1007/s11095-0151844-6.

120. Sun M, Gao Y, Pei Y, Guo C, Li H, Cao F, et al. Development of nanosuspension formulation for oral delivery of quercetin. $\mathrm{J}$ Biomed Nanotechnol. 2010;6(4):325-32.

121. Zhou W, Tan X, Shan J, Liu T, Cai B, Di L. Effect of chitooligosaccharide on the intestinal absorptions of phenylethanoid glycosides in Fructus Forsythiae extract. Phytomedicine. 2014;21(12):1549-58. https://doi.org/10.1016/j.phymed.2014. 06.016 .

122. Zhou W, Yin A, Shan J, Wang S, Cai B, Di L. Study on the rationality for antiviral activity of Flos Lonicerae japonicaefructus Forsythiae herb chito-oligosaccharide via Integral Pharmacokinetics. Molecules. 2017;22(4):E654. https://doi.org/ 10.3390/molecules22040654.

123. Sermkaew N, Ketjinda W, Boonme P, Phadoongsombut N, Wiwattanapatapee R. Liquid and solid self-microemulsifying drug delivery systems for improving the oral bioavailability of andrographolide from a crude extract of Andrographis paniculata. Eur J Pharm Sci. 2013;50(3-4):459-66. https://doi.org/10.1016/j. ejps.2013.08.006.

124. Jiang Y, Wang F, Xu H, Liu H, Meng Q, Liu W. Development of andrographolide loaded PLGA microspheres: optimization, characterization and in vitro-in vivo correlation. Int $\mathrm{J}$ Pharm. 2014;475(1-2):475-84. https://doi.org/10.1016/j.ijpharm.2014. 09.016 .

125. Qiao H, Chen L, Rui T, Wang J, Chen T, Fu T, et al. Fabrication and in vitro/in vivo evaluation of amorphous andrographolide nanosuspensions stabilized by d-alpha-tocopheryl polyethylene glycol 1000 succinate/sodium lauryl sulfate. Int J Nanomedicine. 2017;12:1033-46. https://doi.org/10.2147/IJN.S120887.

126. Xu J, Ma Y, Xie Y, Chen Y, Liu Y, Yue P, et al. Design and evaluation of novel solid self-nanodispersion delivery system for andrographolide. AAPS PharmSciTech. 2017;18(5):1572-84. https://doi.org/10.1208/s12249-016-0627-7.

127. Yang T, Sheng HH, Feng NP, Wei H, Wang ZT, Wang CH. Preparation of andrographolide-loaded solid lipid nanoparticles and their in vitro and in vivo evaluations: characteristics, release, absorption, transports, pharmacokinetics, and antihyperlipidemic activity. J Pharm Sci. 2013;102(12):4414-25. https://doi.org/10. 1002/jps.23758.

128. Ren K, Zhang Z, Li Y, Liu J, Zhao D, Zhao Y, et al. Physicochemical characteristics and oral bioavailability of andrographolide complexed with hydroxypropyl-beta-cyclodextrin. Pharmazie. 2009;64(8):515-20.

129. Akbar MU, Zia KM, Nazir A, Iqbal J, Ejaz SA, Akash MSH. Pluronic-based mixed polymeric micelles enhance the therapeutic potential of curcumin. AAPS PharmSciTech. 2018;19(6):2719 39. https://doi.org/10.1208/s12249-018-1098-9. 
130. Duan Y, Zhang B, Chu L, Tong HH, Liu W, Zhai G. Evaluation in vitro and in vivo of curcumin-loaded mPEG-PLA/TPGS mixed micelles for oral administration. Colloids Surf B Biointerfaces. 2016;141:345-54. https://doi.org/10.1016/j.colsurfb.2016.01. 017.

131. Ramalingam P, Ko YT. Enhanced oral delivery of curcumin from $\mathrm{N}$-trimethyl chitosan surface-modified solid lipid nanoparticles: pharmacokinetic and brain distribution evaluations. Pharm Res. 2015;32(2):389-402. https://doi.org/10.1007/s11095-014-1469-1.

132. Sorasitthiyanukarn FN, Ratnatilaka Na Bhuket P, Muangnoi C, Rojsitthisak P, Rojsitthisak P. Chitosan/alginate nanoparticles as a promising carrier of novel curcumin diethyl diglutarate. Int $\mathrm{J}$ Biol Macromol. 2019;131:1125-36. https://doi.org/10.1016/j. ijbiomac.2019.03.120.

133. Hou Y, Wang H, Zhang F, Sun F, Xin M, Li M, et al. Novel selfnanomicellizing solid dispersion based on rebaudioside A: a potential nanoplatform for oral delivery of curcumin. Int $\mathrm{J}$ Nanomedicine. 2019;14:557-71. https://doi.org/10.2147/IJN. S191337.

134. Wang R, Han J, Jiang A, Huang R, Fu T, Wang L, et al. Involvement of metabolism-permeability in enhancing the oral bioavailability of curcumin in excipient-free solid dispersions co-formed with piperine. Int J Pharm. 2019;561:9-18. https:// doi.org/10.1016/j.ijpharm.2019.02.027.

135. Nazari-Vanani R, Moezi L, Heli H. In vivo evaluation of a selfnanoemulsifying drug delivery system for curcumin. Biomed Pharmacother. 2017;88:715-20. https://doi.org/10.1016/j.biopha. 2017.01.102.

136. Jaisamut P, Wiwattanawongsa K, Graidist P, Sangsen Y, Wiwattanapatapee R. Enhanced oral bioavailability of curcumin using a supersaturatable self-microemulsifying system incorporating a hydrophilic polymer; in vitro and in vivo investigations. AAPS PharmSciTech. 2018;19(2):730-40. https://doi.org/10. 1208/s12249-017-0857-3.

137. Tian C, Asghar S, Wu Y, Chen Z, Jin X, Yin L, et al. Improving intestinal absorption and oral bioavailability of curcumin via taurocholic acid-modified nanostructured lipid carriers. Int $\mathrm{J}$ Nanomedicine. 2017;12:7897-911. https://doi.org/10.2147/IJN. S145988.

138. Kheiri Manjili H, Ghasemi P, Malvandi H, Mousavi MS, Attari E, Danafar H. Pharmacokinetics and in vivo delivery of curcumin by copolymeric mPEG-PCL micelles. Eur J Pharm Biopharm. 2017;116:17-30. https://doi.org/10.1016/j.ejpb.2016.10.003.

139. Aqil F, Munagala R, Jeyabalan J, Agrawal AK, Gupta R. Exosomes for the enhanced tissue bioavailability and efficacy of curcumin. AAPS J. 2017;19(6):1691-702. https://doi.org/10. 1208/s12248-017-0154-9.

140. Khan AW, Kotta S, Ansari SH, Sharma RK, Ali J. Selfnanoemulsifying drug delivery system (SNEDDS) of the poorly water-soluble grapefruit flavonoid Naringenin: design, characterization, in vitro and in vivo evaluation. Drug Deliv. 2015;22(4): 552-61. https://doi.org/10.3109/10717544.2013.878003.

141. Khan AW, Kotta S, Ansari SH, Sharma RK, Ali J. Enhanced dissolution and bioavailability of grapefruit flavonoid Naringenin by solid dispersion utilizing fourth generation carrier. Drug Dev Ind Pharm. 2015;41(5):772-9. https://doi.org/10.3109/ 03639045.2014.902466.

142. Chaurasia S, Patel RR, Vure P, Mishra B. Potential of cationicpolymeric nanoparticles for oral delivery of naringenin: in vitro and in vivo investigations. J Pharm Sci. 2018;107(2):706-16. https://doi.org/10.1016/j.xphs.2017.10.006.

143. Ji P, Yu T, Liu Y, Jiang J, Xu J, Zhao Y, et al. Naringenin-loaded solid lipid nanoparticles: preparation, controlled delivery, cellular uptake, and pulmonary pharmacokinetics. Drug Des Devel Ther. 2016;10:911-25. https://doi.org/10.2147/DDDT.S97738.
144. Wang Y, Wang S, Firempong CK, Zhang H, Wang M, Zhang Y, et al. Enhanced solubility and bioavailability of naringenin via liposomal nanoformulation: preparation and in vitro and in vivo evaluations. AAPS PharmSciTech. 2017;18(3):586-94. https:// doi.org/10.1208/s12249-016-0537-8.

145. Gera S, Talluri S, Rangaraj N, Sampathi S. Formulation and evaluation of naringenin nanosuspensions for bioavailability enhancement. AAPS PharmSciTech. 2017;18(8):3151-62. https://doi.org/ 10.1208/s12249-017-0790-5.

146. Singh MK, Pooja D, Ravuri HG, Gunukula A, Kulhari H, Sistla R. Fabrication of surfactant-stabilized nanosuspension of naringenin to surpass its poor physiochemical properties and low oral bioavailability. Phytomedicine. 2018;40:48-54. https://doi.org/10. 1016/j.phymed.2017.12.021.

147. Shulman M, Cohen M, Soto-Gutierrez A, Yagi H, Wang H, Goldwasser J, et al. Enhancement of naringenin bioavailability by complexation with hydroxypropyl-beta-cyclodextrin. [corrected]. PLoS One. 2011;6(4):e18033. https://doi.org/10. 1371/journal.pone.0018033.

148. Xu C, Tang Y, Hu W, Tian R, Jia Y, Deng P, et al. Investigation of inclusion complex of honokiol with sulfobutyl ether-beta-cyclodextrin. Carbohydr Polym. 2014;113:9-15. https://doi.org/10. 1016/j.carbpol.2014.06.059.

149. Qiu N, Cai LL, Xie D, Wang G, Wu W, Zhang Y, et al. Synthesis, structural and in vitro studies of well-dispersed monomethoxypoly(ethylene glycol)-honokiol conjugate micelles. Biomed Mater. 2010;5(6):065006. https://doi.org/10.1088/1748-6041/5/6/ 065006.

150. Gou M, Zheng L, Peng X, Men K, Zheng X, Zeng S, et al. Poly(epsilon-caprolactone)-poly(ethylene glycol)-poly(epsiloncaprolactone) (PCL-PEG-PCL) nanoparticles for honokiol delivery in vitro. Int J Pharm. 2009;375(1-2):170-6. https://doi.org/10. 1016/j.ijpharm.2009.04.007.

151. Yang R, Huang X, Dou J, Zhai G, Su L. Self-microemulsifying drug delivery system for improved oral bioavailability of oleanolic acid: design and evaluation. Int J Nanomedicine. 2013;8:2917-26. https://doi.org/10.2147/IJN.S47510.

152. Xia X, Liu H, Lv H, Zhang J, Zhou J, Zhao Z. Preparation, characterization, and in vitro/vivo studies of oleanolic acid-loaded lactoferrin nanoparticles. Drug Des Devel Ther. 2017;11:141727. https://doi.org/10.2147/DDDT.S133997.

153. Li W, Das S, Ng KY, Heng PW. Formulation, biological and pharmacokinetic studies of sucrose ester-stabilized nanosuspensions of oleanolic Acid. Pharm Res. 2011;28(8): 2020-33. https://doi.org/10.1007/s11095-011-0428-3.

154. Li W, Ng KY, Heng PW. Development and evaluation of optimized sucrose ester stabilized oleanolic acid nanosuspensions prepared by wet ball milling with design of experiments. Biol Pharm Bull. 2014;37(6):926-37.

155. Xi J, Chang Q, Chan CK, Meng ZY, Wang GN, Sun JB, et al. Formulation development and bioavailability evaluation of a selfnanoemulsified drug delivery system of oleanolic acid. AAPS PharmSciTech. 2009;10(1):172-82. https://doi.org/10.1208/ s12249-009-9190-9.

156. Tian C, Asghar S, Wu Y, Kambere Amerigos D, Chen Z, Zhang $\mathrm{M}$, et al. N-acetyl-L-cysteine functionalized nanostructured lipid carrier for improving oral bioavailability of curcumin: preparation, in vitro and in vivo evaluations. Drug Deliv. 2017;24(1):1605-16. https://doi.org/10.1080/10717544.2017.1391890.

157. Pouton CW, Porter CJ. Formulation of lipid-based delivery systems for oral administration: materials, methods and strategies. Adv Drug Deliv Rev. 2008;60(6):625-37. https://doi.org/10. 1016/j.addr.2007.10.010.

158. McClements DJ (2018) Advances in nanoparticle and microparticle delivery systems for increasing the dispersibility, stability, and 
bioactivity of phytochemicals. Biotechnol Adv. https://oi.org/10. 1016/j.biotechadv.2018.08.004

159. Patel V, Lalani R, Bardoliwala D, Ghosh S, Misra A. Lipid-based oral formulation strategies for lipophilic drugs. AAPS PharmSciTech. 2018;19(8):3609-30. https://doi.org/10.1208/ s12249-018-1188-8.

160. Dahan A, Hoffman A. The effect of different lipid based formulations on the oral absorption of lipophilic drugs: the ability of in vitro lipolysis and consecutive ex vivo intestinal permeability data to predict in vivo bioavailability in rats. Eur $\mathrm{J}$ Pharm Biopharm. 2007;67(1):96-105. https://doi.org/10.1016/j.ejpb. 2007.01.017.

161. Dahan A, Hoffman A. Rationalizing the selection of oral lipid based drug delivery systems by an in vitro dynamic lipolysis model for improved oral bioavailability of poorly water soluble drugs. J Control Release. 2008;129(1):1-10. https://doi.org/10.1016/j. jconrel.2008.03.021.

162. Beig A, Agbaria R, Dahan A. The use of captisol (SBE7-beta-CD) in oral solubility-enabling formulations: comparison to HPbetaCD and the solubility-permeability interplay. Eur J Pharm Sci. 2015;77:73-8. https://doi.org/10.1016/j.ejps.2015.05.024.

163. Beig A, Miller JM, Dahan A. The interaction of nifedipine with selected cyclodextrins and the subsequent solubility-permeability trade-off. Eur J Pharm Biopharm. 2013;85(3 Pt B):1293-9. https:// doi.org/10.1016/j.ejpb.2013.05.018.

164. Miller JM, Dahan A. Predicting the solubility-permeability interplay when using cyclodextrins in solubility-enabling formulations: model validation. Int J Pharm. 2012;430(1-2):388-91. https://doi. org/10.1016/j.ijpharm.2012.03.017.

165. Amidon GE, Higuchi WI, Ho NF. Theoretical and experimental studies of transport of micelle-solubilized solutes. J Pharm Sci. 1982;71(1):77-84. https://doi.org/10.1002/jps.2600710120.

166. Beig A, Miller JM, Lindley D, Dahan A. Striking the optimal solubility-permeability balance in oral formulation development for lipophilic drugs: maximizing Carbamazepine blood levels. Mol Pharm. 2017;14(1):319-27. https://doi.org/10.1021/acs. molpharmaceut.6b00967.

167. Fine-Shamir N, Dahan A. Methacrylate-copolymer Eudragit EPO as a solubility-enabling excipient for anionic drugs: investigation of drug solubility, intestinal permeability, and their interplay. Mol Pharm. 2019;16(7):2884-91. https://doi.org/10.1021/acs. molpharmaceut.9b00057.

168. Beig A, Lindley D, Miller JM, Agbaria R, Dahan A. Hydrotropic solubilization of lipophilic drugs for oral delivery: the effects of urea and nicotinamide on carbamazepine solubility-permeability interplay. Front Pharmacol. 2016;7:379. https://doi.org/10.3389/ fphar.2016.00379.

169. Dahan A, Beig A, Lindley D, Miller JM. The solubilitypermeability interplay and oral drug formulation design: two heads are better than one. Adv Drug Deliv Rev. 2016;101:99 107. https://doi.org/10.1016/j.addr.2016.04.018.

Publisher's note Springer Nature remains neutral with regard to jurisdictional claims in published maps and institutional affiliations. 